\title{
The Use of Inverters in Solar Power Plants for Alternating Current Loads
}

\author{
Noorly Evalina ${ }^{1}$, Faisal Irsan Pasaribu ${ }^{2}$, Abdul Azis $\mathbf{H}^{3}$ \\ 12,3Universitas Muhammadiyah Sumatera Utara, Indonesia \\ Email: noorlyevalina@umsu.ac.id
}

\begin{abstract}
:
The sun shines on the territory of Indonesia for about 10 to 12 hours every day, so that solar power plants can be developed in Indonesia, the government has launched the movement of one million PLTS roofs in 2017, this research uses solar panels with a capacity of $200 \mathrm{Wp}$, which consists of 2 solar panels connected in parallel, solar charge controllers, batteries, inverters and as an AC load a fan, soldering iron and LED lights, the research aims to determine the output current, voltage and output power of the inverter when given an alternating current load that is inductive, resistive and capacitive, the method used is to measure the intensity of the sun, temperature, voltage, electric current, power factor, when the load is large the voltage drops depending on the given load, the inductive fan load has a voltage drop that is greater than the voltage drop that occurs in the soldering load and the LED lamp, the large current flowing on the output side fan load wants to be bigger than output current flowing in the solder and LED lights, the low efficiency of the inverter used can shorten the life of the electrical equipment used.
\end{abstract}

Keywords:

sunlight intensity; solar panel; battery, inverter; AC load

\section{Introduction}

The potential of solar energy in Indonesia is very large, is more than $207.8 \mathrm{GWp}$, the utilization of solar energy is very important to replace fossil energy as a new and renewable power source, the realization of the roof as a solar power plant is very possible, especially in private and government offices and has been proclaimed in 2017 with the movement of a million solar power plant roofs, The utilization of the roof as a power plant strongly supports the fulfillment of new renewable energy needs in every region, especially as an energy source in areas that have not been reached by the distribution of electricity by PT. PLN (Harahap, 2021).

\section{Review of Literatures}

The instalLED capacity of a solar power plant is affected by the capacity of solar panels, solar charge controllers, batteries, and inverters (Benda, 2020), the temperature and intensity of sunlight also affect the magnitude of the voltage produced in photovoltaic (Masri, 2014), the direct current voltage produced by photovoltaic will be greater if the intensity of light received by photovoltaics is greater (Irwanto, 2019).

Photovoltaics can be connected in series or parallels, to produce constant currents and higher voltages can be done by connecting multiple photovoltaics as a series (Siregar, 2021), to obtain a constant voltage and a larger current photovoltaic can be connected parallelly, in accordance with Kirchoff's law. 


\section{Britain International of Exact Sciences (BIoEx) Journal}

ISSN: 2686-1208 (Online), 2686-1216 (Print)

Vol. 3, No. 3, September 2021, Page: 151-158

Email:bioexjournal@gmail.com

The direct-current voltage generated by solar panels will be charged to the battery by a solar charge controller, the solar charge controller is also used to avoid overcharging the battery (Hidayat, 2021), which can cause damage to the battery, the tool needed to store the electrical energy generated by solar power plants is a battery so that the load can receive alternating current electrical energy without sunlight (Pasaribu, 2021; Roberts, 2019).

Alternating current voltage in solar power plants is generated by inverters, inverters are tools that can convert direct current (DC) electrical voltage provided by batteries into alternating current voltage, used as a source of alternating current voltage needed by electricity load, power losses can occur in the use of inverters in solar power plants (Evalina, 2019), voltage of 220 Volts can be generated by inverters according to electricity usage in Indonesia, to maintain the lifespan of electrical equipment that uses PLTS, the quality of electrical voltage produced by the inverter must be maintained (Evalina, 2021).

\section{Research Methods}

This research was conducted outside the umsu electrical engineering laboratory, block diagrams of the following:

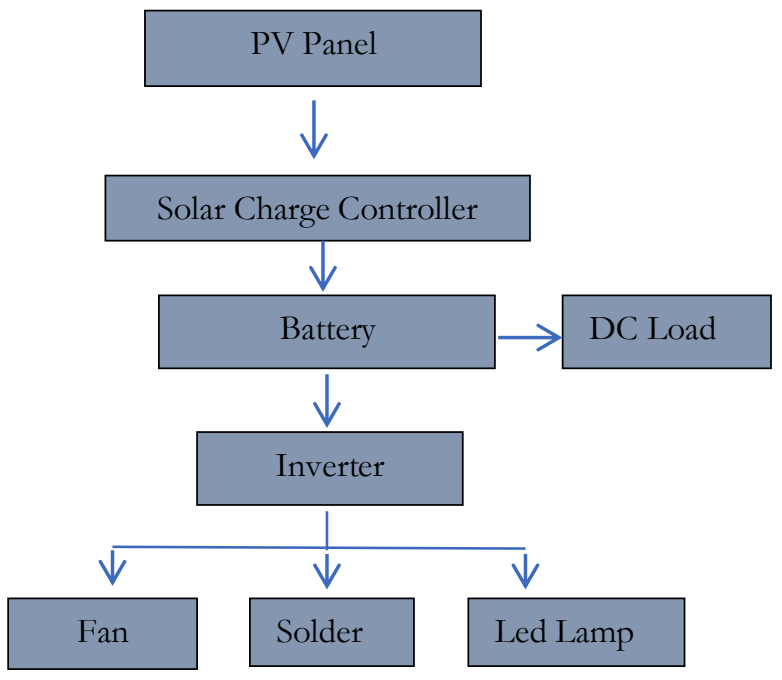

Figure 1. Block of Research Diagram

Figure 1, showing the block of research diagram, solar panels with a capacity of 200 $\mathrm{Wp}$, is a parallel relationship of 2 photovoltaics with a capacity of $100 \mathrm{Wp}$, will receive the intensity of sunlight and will convert it into electrical energy in the form of direct current voltage (DC) shown figure 2, solar panels provide direct current voltage supply on the solar charge controller that serves to charge a battery with a capacity of 12 volts dc 60 , AH, When the battery is fully charged the solar charge controller will stop charging the battery, the battery will send a voltage to the inverter that will be converted into a good alternating current voltage of $220 \mathrm{~V}$ [11], the inverter will provide supply voltage on the load 45 watts fan, 40 watts solder and 15 watts LED light. 


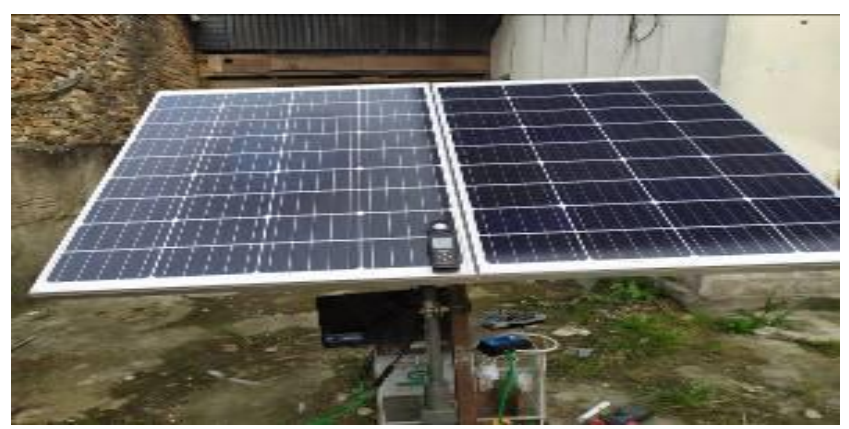

Figure 2. PV Array Testing

The research has several stages, namely preparing the equipment to be used, connecting all the equipment, and conducting 8 measurements, which aim to measure the magnitude of the intensity of the sun, measure temperature, measure the output voltage of solar panels, measure battery voltage, measure alternating current voltage on inverters when without load (Irwwanto, 2017).

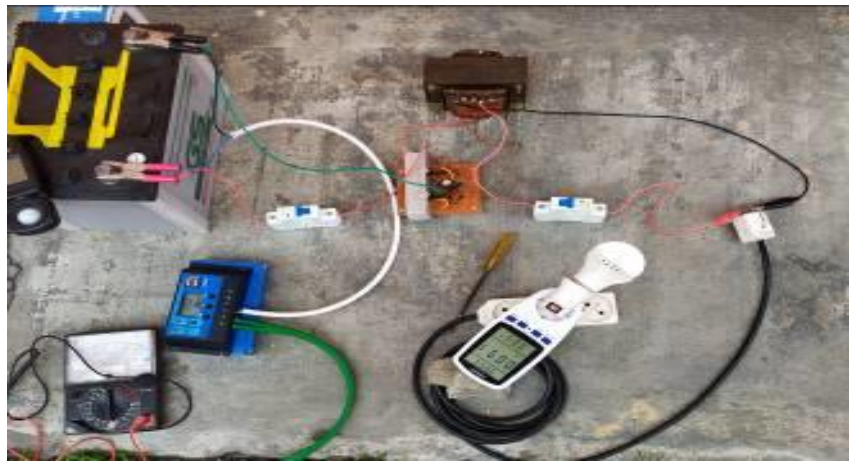

Figure 3. Inverter Testing

Testing when loading is done alternately, figure 3 shows testing using a load of LED lights, in the same way, tests are done on fans and solders, to measure the input voltage and output voltage of the inverter, the current flowing when encumbered by fans, solders and LED lights, after obtaining the desired data can be analyzed for voltage falls that occur in the inverter when loading.

\section{Discussion}

Testing aims to determine the magnitude of voltage, current, power, the intensity of sunlight (Kumar, 2020), the energy required to rotate the fan as inductive load, LED light as a capacitive load, and solder as a resistive load, testing begins by carrying out unloaded testing, to measure the intensity of sunlight, temperature, the amount of voltage produced by photovoltaic, the voltage on the battery, input voltage and output voltage on the inverter.

The data retrieval was conducted outside UMSU's electrical engineering laboratory, a large average sunlight intensity.

Table 1. No Load Test Result

\begin{tabular}{cccccc}
\hline $\begin{array}{c}\text { Time } \\
\text { (hours) }\end{array}$ & $\begin{array}{c}\text { Light } \\
\text { Intensity } \\
\text { (lux) }\end{array}$ & $\begin{array}{c}\text { Temperature } \\
{ }^{\circ} \text { C }\end{array}$ & $\begin{array}{c}\text { Input } \\
\text { Voc } \\
\text { Dc } \\
\text { (V) }\end{array}$ & $\begin{array}{c}\text { Charge } \\
\text { baterai } \\
\text { VDC (V) }\end{array}$ & $\begin{array}{c}\text { Output } \\
\text { VAC (V) }\end{array}$ \\
\hline $08: 00$ & 1226 & 32,9 & 20,1 & 12,6 & 220
\end{tabular}




\begin{tabular}{llllll}
$09: 00$ & 1569 & 32,6 & 21,4 & 12,8 & 220 \\
10.00 & 1462 & 32,1 & 21,4 & 12,6 & 220 \\
$11: 00$ & 1990 & 31,1 & 20,8 & 12,8 & 220 \\
$12: 00$ & 2416 & 31,6 & 20,9 & 12,9 & 220 \\
$13: 00$ & 3251 & 32,3 & 21,0 & 12,8 & 220 \\
$14: 00$ & 4566 & 31,9 & 21,7 & 13,3 & 220 \\
$15: 00$ & 1058 & 31,7 & 7,7 & 12,1 & 220 \\
\hline
\end{tabular}

Table 1, showing the time without the load of the test results of the average light intensity of 2192 lux, the minimum light intensity at 15:00 at 1058 lux and the maximum light intensity of 4566 lux, the average temperature of $32 \mathrm{oC}$, the lowest temperature at 11:00 while the highest temperature at $32.9 \mathrm{oC}$, at 08.00 hours, from the results of this test, proved that the temperature and intensity of sunlight greatly affect the size of voltage that can be produced by the photovoltaic, testing when loading is done by measuring the output voltage on the fan, solder and LED lights, the measurement results are shown table 2.

Table 2. Load Voltage Against Time

\begin{tabular}{cccc}
\hline $\begin{array}{c}\text { Time } \\
\text { (hour) }\end{array}$ & $\begin{array}{c}\text { V fan } \\
\text { (volts) }\end{array}$ & $\begin{array}{c}\text { Vsolder } \\
\text { (volts) }\end{array}$ & $\begin{array}{c}\text { V LED } \\
\text { (volts) }\end{array}$ \\
\hline $08: 00$ & 128,7 & 156,1 & 188,7 \\
$09: 00$ & 139,1 & 156,7 & 186,4 \\
10.00 & 136,1 & 155,3 & 184,1 \\
$11: 00$ & 147,5 & 159,0 & 188,8 \\
$12: 00$ & 144,2 & 162,5 & 185,1 \\
$13: 00$ & 141,7 & 160,7 & 184,5 \\
$14: 00$ & 140,1 & 161,8 & 184,6 \\
$15: 00$ & 135,3 & 154,2 & 183,8 \\
\hline
\end{tabular}

From the test results obtained the average voltage used load is for a fan of 139.09 volts, solder 158.29 volts, and for LED lights 185, 38 volts, LED lights that are capacitors are greater using inverter voltage than a solder that is resistive and fan that is inductive seen in table 2 , the percentage of voltage fall can be calculated by measuring the output voltage on the inverter when without load and when loading on the fan, when taken from the results of measurement.

$$
\begin{gathered}
V d=\frac{V_{N L}-V_{F L}}{V_{N L}} \times 100 \% \\
V d=\frac{220-128,7}{220} \times 100 \% \\
V d=\frac{220-128,7}{220} \times 100 \% \\
V d=41,5 \%
\end{gathered}
$$

In the same way, the voltage falls on the solder load by $29 \%$ and at the load of the LED lamp $14.2 \%$, from the test results, it is known that the smallest voltage fall occurs in the LED load and the largest voltage fall occurs at the fan load of $41.5 \%$. 


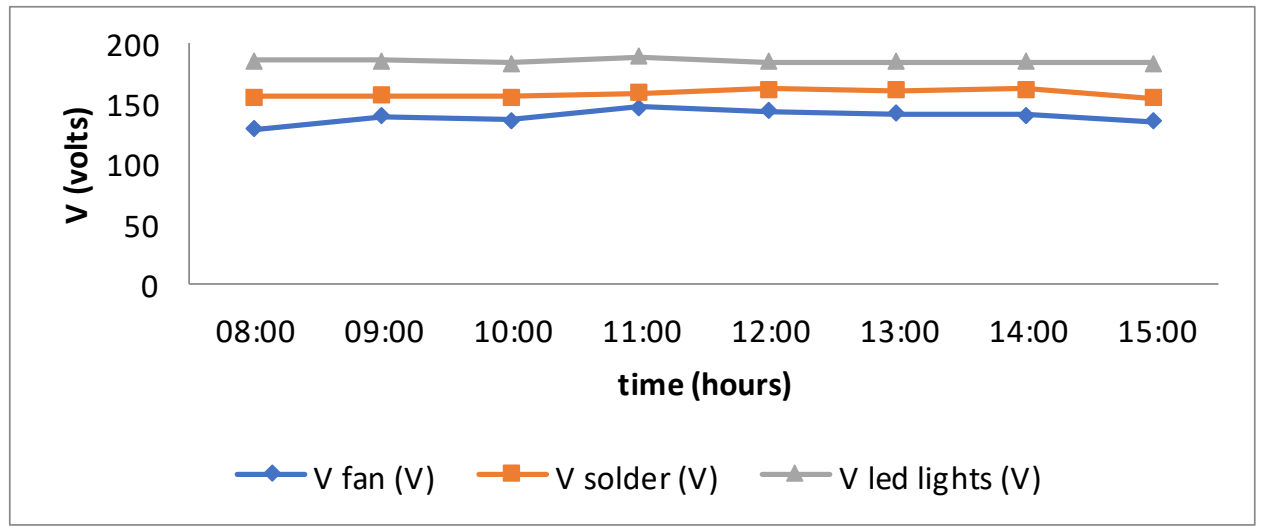

Figure 4. Voltage Graphic on Load

Figure 4. shows the average voltage in LED lights higher than the average voltage on fans and solderers.

Table 3. Load Current Against Time

\begin{tabular}{cccc}
\hline $\begin{array}{c}\text { Time } \\
\text { (jam) }\end{array}$ & $\begin{array}{c}\text { I fan } \\
\text { (ampere) }\end{array}$ & $\begin{array}{c}\text { Isolder } \\
\text { (Ampere) }\end{array}$ & $\begin{array}{c}\text { I LED light } \\
\text { (Ampere) }\end{array}$ \\
\hline $08: 00$ & 0,157 & 0,085 & 0,091 \\
$09: 00$ & 0,142 & 0,087 & 0,084 \\
10.00 & 0,140 & 0,085 & 0,089 \\
$11: 00$ & 0,143 & 0,086 & 0,082 \\
$12: 00$ & 0,141 & 0,084 & 0,083 \\
$13: 00$ & 0,140 & 0,086 & 0,090 \\
$14: 00$ & 0,137 & 0,087 & 0,089 \\
$15: 00$ & 0,135 & 0,084 & 0,087 \\
\hline
\end{tabular}

From the test results obtained that the average current with 8 times the test point, consumed by a fan load of 0.142 Ampere, solder 0.086 Ampere, and LED lamp 0.087 Ampere shown table 3 .

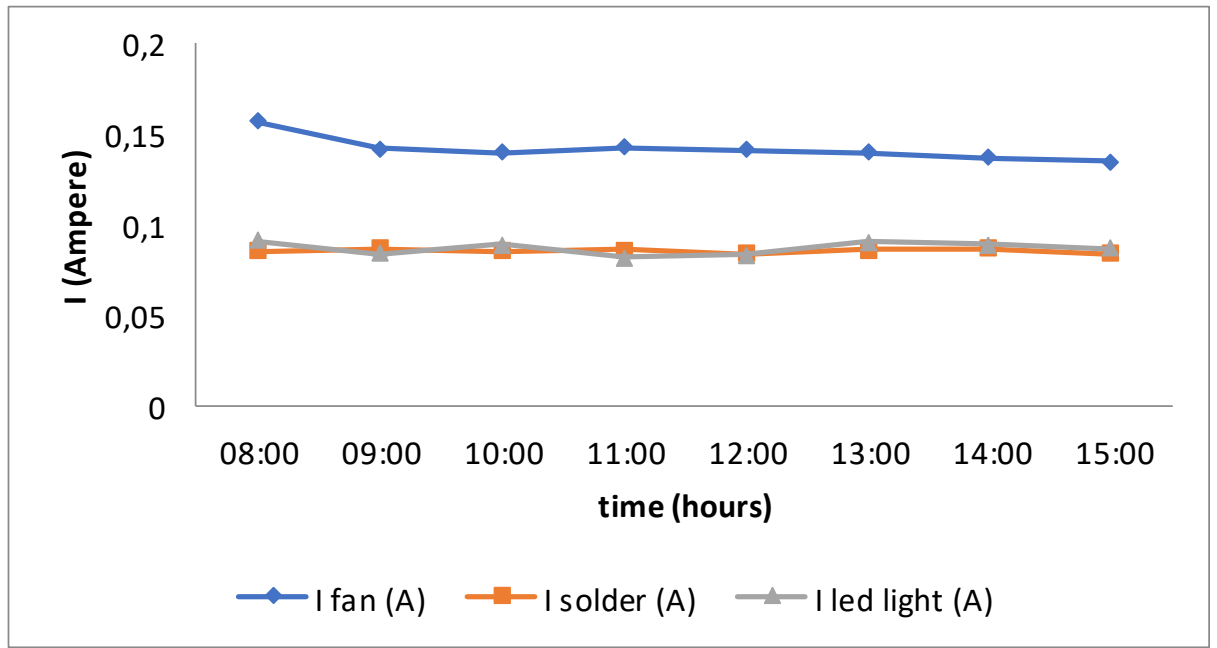

Figure 5. The Average Power on Soldering and LED Lights

Figure 5. Showing the fan load the electric current flowing is greater than the electric current flowing on solder loads and LED lights. 
Table 4. Load Power against Time

\begin{tabular}{cccc}
\hline $\begin{array}{c}\text { time } \\
\text { (hours) }\end{array}$ & $\begin{array}{c}\text { P fan } \\
\text { (watts) }\end{array}$ & $\begin{array}{c}\text { P solder } \\
\text { (watts) }\end{array}$ & $\begin{array}{c}\text { P LED light } \\
\text { (watts) }\end{array}$ \\
\hline $08: 00$ & 19 & 12,87 & 0,85 \\
$09: 00$ & 17,8 & 12,90 & 1,38 \\
10.00 & 16,9 & 13,4 & 1,1 \\
$11: 00$ & 17,7 & 13,2 & 1,36 \\
$12: 00$ & 17,3 & 13,0 & 1,2 \\
$13: 00$ & 17,0 & 13,5 & 1,0 \\
$14: 00$ & 16,8 & 14,3 & 0,9 \\
$15: 00$ & 15,9 & 13,1 & 1,1 \\
\hline
\end{tabular}

From the test results in table 4, it can be calculated the average power on the fan with 8 times the test point, in the same way the average power on solder and LED lights is 13.3 watts and 1.1 watts.

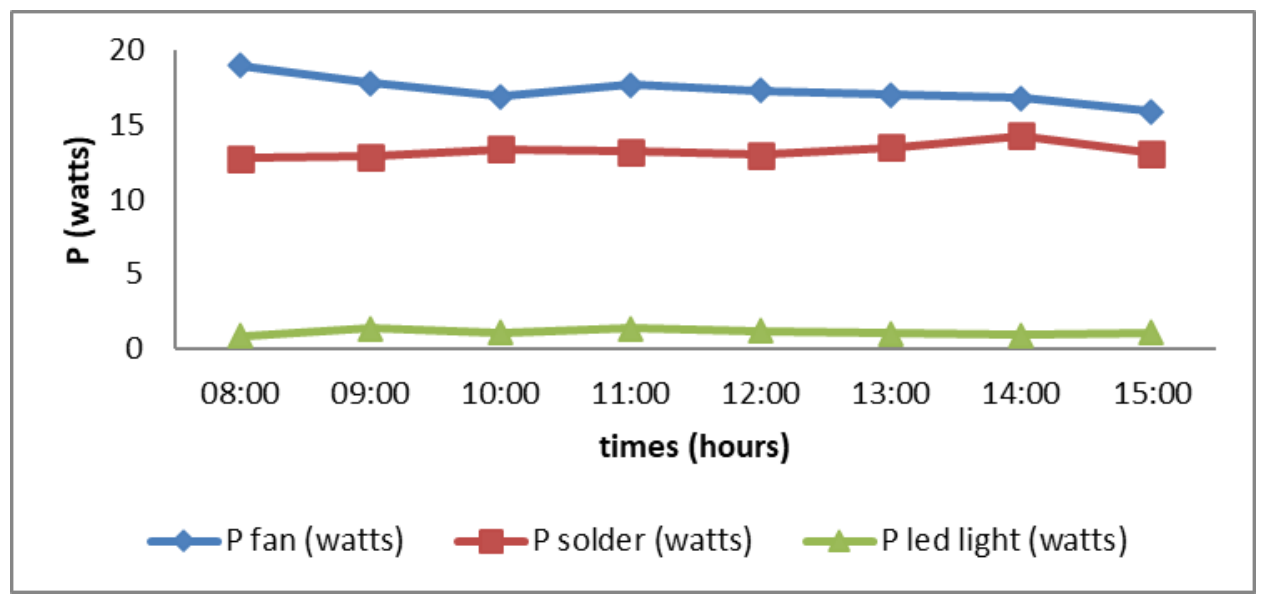

Figure 6. Showing A Large Power on the Fan Greater than the Average Power on Soldering and LED Lights

Table 5. Fan Load Testing Results

\begin{tabular}{ccccc}
\hline $\begin{array}{c}\text { Vdc } \\
\text { (volt) }\end{array}$ & $\begin{array}{c}\text { Idc } \\
\text { (A) }\end{array}$ & $\begin{array}{c}\text { Vac } \\
\text { (volt) }\end{array}$ & $\begin{array}{c}\text { Iac } \\
(\mathbf{A})\end{array}$ & pf \\
\hline 12,6 & 3,66 & 128,7 & 0,157 & 0,94 \\
12,8 & 3,53 & 139,1 & 0,142 & 0,86 \\
12,6 & 3,64 & 136,1 & 0,140 & 0,84 \\
12,8 & 3,61 & 147,5 & 0,143 & 0,86 \\
12,9 & 3,59 & 144,2 & 0,141 & 0,84 \\
12,8 & 3,65 & 141,7 & 0,140 & 0,84 \\
13,3 & 3,58 & 140,1 & 0,137 & 0,83 \\
12,1 & 3,46 & 135,3 & 0,135 & 0,82 \\
\hline
\end{tabular}

The voltage falling on the fan is greater than the voltage falling on solder loads and LED lights, so the calculation of inverter efficiency on inductive load in this case the fan based on table 5 .

Data on the first test of the amount of input power from table 5.

$$
\begin{aligned}
\text { Pinput }=P d c=V d c . I d c \\
P d c=12,6 \times 3,66 \\
P d c=46,11 \text { watts }
\end{aligned}
$$


The amount of output power can be calculated

$$
\begin{gathered}
\text { Poutput }=\text { Pac }=\text { Vac. Iac.pf } \\
\text { Pac }=128,7 \times 0,157 \times 0,94 \\
\text { Pac }=18,99 \text { watt }
\end{gathered}
$$

From the amount of input power and output that has been calculated before, obtained the amount of efficiency when the inverter dberi fan load:

$$
\begin{aligned}
& \text { efficiency }=\frac{\text { Poutput }}{\text { Pinput }} \\
& \text { efficiency }=\frac{18,99}{46,11} \times 100 \% \\
& \text { efficiency }=41,2 \%
\end{aligned}
$$

In the same way, it can be calculated the efficiency of each fan testing point, see table 6

Table 6. Efficiency In Inverter

\begin{tabular}{ccc}
\hline Pdc (watt) & $\begin{array}{c}\text { Pac } \\
\text { (watt) }\end{array}$ & $\begin{array}{c}\text { Efficiency } \\
\text { inverter (\%) }\end{array}$ \\
\hline 46,11 & 18,9 & 41,2 \\
44,48 & 17,8 & 40 \\
45,86 & 16,9 & 36,8 \\
46,20 & 17,7 & 38,3 \\
46,31 & 17,3 & 37,4 \\
46,72 & 17,0 & 36,4 \\
47.61 & 16,8 & 35,3 \\
41,86 & 15,9 & 37,9 \\
\hline
\end{tabular}

Table 6. Showing that the average efficiency value of the inverter on a low fan is about $38.11 \%$, this is shown by the slow rotation of the fan motor, due to power losses that occur in the inverter, this can shorten the life of the fan used.

\section{Conclusions}

Solar panels $200 \mathrm{Wp}$ from the results of the study, able to produce a direct current voltage from the photovoltaic that will be charged to the battery by the solar charge controller, the battery will send a direct current voltage to the inverter which is converted into an alternating current voltage of 220 volts as a source of energy at the load, falling voltage on the fan load greater than the voltage fall on solder and LED lights, The efficiency of the inverter used from low testing results, due to power losses in the inverter, this can shorten the life of the electrical equipment used.

\section{Acknowledgments}

Thank internal grant aid that has been given by APB UMSU by contract number: 261/II. 3AU/UMSU-LP2M/C/2021, so the research can be executed. 


\section{References}

Ahmed, T.A., E. E. M. Mohamed, A. R. Youssef, A. A. Ibrahim, M. S. R. Saeed, and A. I. M. Ali, "Three-phase modular multilevel inverter-based multi-terminal asymmetrical DC inputs for renewable energy applications," Eng. Sci. Technol. an Int. J., vol. 23, no. 4, pp. 831-839, 2020, doi: 10.1016/j.jestch.2019.11.003.

Benda, V., and Černá, L. "PV cells and modules - State of the art, limits and trends," Heliyon, vol. 6, no. 12, pp. 1-8, 2020, doi: 10.1016/j.heliyon. 2020.e05666.

Evalina, N., A. Azis H, Rimbawati, and Cholish, "Efficiency analysis on the inverter using the energy-saving lamp," IOP Conf. Ser. Mater. Sci. Eng., vol. 674, no. 1, 2019, doi: 10.1088/1757-899X/674/1/012034.

Evalina, N., F. I. Pasaribu, A. A. A. H, and R. D. Ivana, "Implementasi Pembangkit Listrik Tenaga Surya Kapasitas 200 Wp Dengan Sistem Solar Charger Pada Beban Kipas Angin," 2021.

Harahap, P., I. Nofri, and S. Lubis, "PLTS 200 Wp to Meet Energy Needs at the Taqwa Muhammadiyah Mosque, Sei Litur Village, Sawit Sebrang Langkat District,” J. Innov. Community Engagem., vol. 1, no. 1, pp. 60-71, 2021, doi: 10.28932/jice. v1i1.3380.

Hidayat, K., M. C. Hasani, N. A. Mardiyah, and M. Effendy, "Strategi Pengisian Baterai pada Sistem Panel Surya Standalone Berbasis Kontrol PI Multi - Loop,” vol. 13, no. 1, 2021.

Irwanto, M., M. Masri, B. Ismail, and Y. Lew, WZ, Irwan, "Solar energy density estimation using ANFIS based on daily maximum and minimum temperature," Int. J. Power Electron. Drive Syst., vol. 10, no. 4, p. 11591, 2019, doi: 10.11591/ijpeds. v10.i4.22062213.

Kumar, N.M., et al., "Solar PV module technologies," Photovolt. Sol. Energy Convers., pp. 51-78, 2020, doi: 10.1016/b978-0-12-819610-6.00003-x.

Masri, M., R. Badlishah, M. Irwanto, and H. Alam, "Solar Radiation Potential as Energy Source of Photovoltaic Powered Uninterrupted Power Supply in Perlis, Northern Malaysia," IOSR J. Electr. Electron. Eng., vol. 9, no. 6, pp. 31-36, 2014, doi: 10.9790/1676-09623136.

Pasaribu, F.I and M. Reza, "Rancang Bangun Charging Station Berbasis Arduino Menggunakan Solar Cell 50 WP," R E L E (Rekayasa Elektr. dan Energi) J. Tek. Elektro, vol. 3, no. 2, pp. 46-55, 2021.

Roberts, M.B., A. Bruce, and I. MacGill, "Impact of shared battery energy storage systems on photovoltaic self-consumption and electricity bills in apartment buildings," Appl. Energy, vol. 245, no. March, pp. 78-95, 2019, doi: 10.1016/j.apenergy.2019.04.001.

Siregar, M., N. Evalina, and M. Z. Haq, "Analisa Hubungan Seri Dan Paralel Terhadap Karakteristik Solar Sel Di Kota Medan,” vol. 3, no. 2, pp. 94-100, 2021., 